JACEK WAtDOCH

iD http:/orcid.org/0000-0003-3359-1188

Uniwersytet Gdański

\title{
Sprawa rozwiazania krakowskiej Rady Miejskiej w 1924 r.
}

\author{
Abstract \\ The Case of the Dissolution of the Kraków City Council in 1924
}

This study was devoted to the investigation of the case of the dissolution of the Kraków City Council in 1924 and the consequences resulting from this decision. After the death of the President of Kraków, Jan Kanty Federowicz, the supervisory authority (i.e. the voivode) decided to dissolve the City Council and appoint a government commissioner and a supervisory board. The commissioner was associated with the central government, while the members of the board mostly represented the ruling coalition. The councilors objected to this decision and appealed it to the Supreme Administrative Tribunal, which ultimately agreed with them. It was found that the voivode had issued the decision for dissolution in breach of the law. The controversial judgment was commented on by lawyers and criticized by those who contended that the Tribunal had errouneously based its decision rely on archaic legislation.

Keywords: local self-government, Cracow, supervision, inter-war period, Second Polish Republic

Słowa kluczowe: samorząd terytorialny, Kraków, nadzór, dwudziestolecie międzywojenne, II Rzeczpospolita

To była jedna z pierwszych i zarazem najgłośniejszych spraw, w której Rada Miejska dużego miasta po jej rozwiązaniu zdecydowała się na wniesienie skargi do Najwyższego Trybunału Administracyjnego. Ze względu na wagę wydarzeń i pozycję Krakowa wydarzenie to stało się przedmiotem szerokich dyskusji nie tylko w środowisku lokalnym. Debata przeniosła się na łamy prasy oraz fachowych czasopism, gdzie prawnicy podejmowali próby analizy stanu prawnego. Kwestia rozwiązania Rady Miejskiej Krakowa dała jednocześnie asumpt do trwającej przez cały okres II Rzeczypospolitej dyskusji nad zakresem nadzoru władzy centralnej nad samorządem terytorialnym.

Krakowski samorząd miejski na początku XX w. funkcjonował na podstawie „Statutu gminnego dla stoł[ecznego] król[ewskiego] miasta Krakowa"1 z 1901 r., który, po kilku

\footnotetext{
1 Statut gminny.
} 
nowelizacjach, obowiązywał do 1933 r. ${ }^{2}$. Cieszący się tą odrębnością ustrojową Kraków z biegiem lat zyskiwał na znaczeniu, stając się dużym, ważnym ośrodkiem miejskim w Galicji ${ }^{3}$. W chwili przejmowania władzy w mieście przez Komisję Likwidacyjną w 1918 r. Krakowem zarządzał Jan Kanty Federowicz, wybrany na urząd 6 marca 1918 r., ciałem uchwałodawczym pozostawała zaś Rada Miejska, której 92 radnych pochodziło z wyborów sprzed wojny (1911 i 1914), 16 zasiliło Radę w 1916 r. w wyniku powiększenia miasta o gminę Podgórze, natomiast 24 radnych pochodziło z nominacji Komisji Likwidacyjnej z 1918 r. ${ }^{4}$.

W dniu 13 lipca 1924 r. ${ }^{5}$ zmarł prezydent Federowicz. Jego śmierć zainicjowała walkę o polityczne wpływy w mieście, w której udział wzięły czołowe ugrupowania polityczne upatrujące w nadchodzących wydarzeniach szansę na swój sukces. Zarząd nad miastem przejął wiceprezydent Józef Sare przygotowujący na 24 lipca wybory uzupełniające na urząd prezydenta. W prasie spekulowano o strategii ugrupowań, przewidując zjednoczenie się lewicy w celu wysunięcia wspólnego kandydata, na co prawa strona sceny politycznej zareagowała nieprzewidzianie - złożyła wniosek o rozwiązanie Rady Miejskiej i ustanowienie komisarza rządowego wobec ustania kadencji organu uchwałodawczego ${ }^{6}$. Chadecja i endecja doskonale zdawały sobie sprawę z niewielkich szans na wygraną w wyborach, dysponowali zaledwie ośmioma mandatami, dlatego jedyną możliwością zablokowania planów lewicy było rozwiązanie reprezentacji gminnej. Trudno jednoznacznie wskazać, czy wniosek o rozwiązanie organów był wyłączną inicjatywą krakowskich radnych, czy inspiracja wypływała z Warszawy, aby pod pozorem

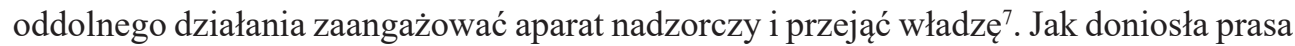
krakowska, 17 lipca 1924 r. posłowie chadecji, Związku Ludowo-Narodowego i PSL wezwali rząd „do natychmiastowego rozwiązania Rady miejskiej i Prezydium miasta Krakowa i do mianowania tymczasowego komisarza rządowego [...]"8.

Dwa dni później, 19 lipca 1924 r., wojewoda krakowski Władysław Kowalikowski wydał decyzję rozwiązującą Radę Miejską i jednocześnie mianował komisarza rządowego w osobie dotychczasowego wicewojewody Zdzisława Wawrauscha. Doradzać mu miała 36-osobowa Rada Przyboczna ${ }^{9}$, zdominowana (połowa miejsc) przez reprezentantów chadecji, endecji i PSL „Piast”, co wynikało z wcześniejszego porozumienia

2 Adamczyk, ,Samorząd Krakowa”, 51.

3 Małecki, „W dobie autonomii”, 226.

4 Adamczyk, „Samorząd Krakowa”, 51; „Rozwiązać Radę m. Krakowa”, Goniec Krakowski 164 (20 lipca 1924), 6; Rekurs Rady Miejskiej stoł[ecznego], król[ewskiego] miasta Krakowa do rąk adw. Dra Stanisława Klimeckiego w Krakowie, ul. św. Anny 7, ANK, AmK, dok. Kr 4422-4424 [b.p.].

5 „S. p. J. K. Federowicz”, Gtos Narodu 159 (16 lipca 1924), 1.

6 „O prezydenturę miasta Krakowa”, Głos Narodu 161 (18 lipca 1924), 9; „O komisarza rządowego dla miasta", Głos Narodu 161 (18 lipca 1924), 9.

7 Kozińska-Witt, „Udział Żydów”, 651-2; „Rozwiązanie Rady Miejskiej”, Kurier Wieczorny 164 (22 lipca 1924), 1.

8 „Kronika krakowska, O komisarza rządowego dla Krakowa”, Gtos Narodu 163 (20 lipca 1924), 6.

9 W skład Rady Przybocznej weszli: Aleksander Adelman, Emil Bobrowski, Stanisław Burtan, Paweł Czuj, Marian Dąbrowski, Tadeusz Epstein, Jan Englisch, Józef Emilewicz, Adolf Gross, Karol Holeksa, Jan Jasiński, Stanisław Klimecki, Piotr Kosobudzki, Ludwik Kasprzyk, Antoni Kolarz, Rafał Landau, Adam Łobaczewski, Adam Miller, Józef Niemczyński, Józef Muczkowski, Franciszek Mussil, Henryk Mianowski, Antoni Mikulski, Michał Nycz, Jan Owiński, Henryk Pachoński, Józef Rosenzweig, Stanisław Rowiński, Stanisław Rymar, Feiwel Stempel, Ludwik Schneider, Wiktor Sedlaczek, Ozjasz Thon, Tadeusz Tabaczyński, Władysław Turski, Fryderyk Zoll. „Komisariat rządowy w Krakowie”, Glos Narodu 167 (25 lipca 1924), 2. 
Chrześcijańskiego Związku Jedności Narodowej i ludowców o utworzeniu koalicji rządzącej ${ }^{10}$. Pomocą w pracy codziennej komisarza służyli pozostawieni na swoich stanowiskach trzej wiceprezydenci: Józef Sare, Karol Rolle oraz Piotr Wielgus ${ }^{11}$. Wojewoda w swojej decyzji dokładnie określił termin rozpoczęcia urzędowania komisarza rządowego na 21 lipca od godziny 9:00, a co istotniejsze, zawarł również powody podjęcia decyzji, stwierdzając, że:

Rada ta, powołana do życia jeszcze w okresie przedwojennym i w większości swej urzędująca już około lat 13, w obecnym składzie zgoła nie odpowiada zmienionym w pośrednim czasie stosunkom społecznym i ekonomicznym miasta, a nadto uzupełniana kilkakrotnie nie w drodze uzupełniających wyborów, lecz sposobem kooptacji, względnie nominacji, zatraciła poniekąd charakter istniejącego legalnie ciała samorządowego, a tym samym i zdolność prawną do przeprowadzania tego rodzaju aktu, jak wybór prezydenta miasta $[\ldots]^{12}$.

Rozwiązanie Rady Miejskiej Krakowa spotkało się z gwałtowną reakcją środowisk politycznych, które poprzez swoje organy prasowe żywo komentowały to wydarzenie. Pisano o działaniu mającym na celu odsunięcie od władzy fachowych radnych, bo ci nie wywodzili się z endecji13, oskarżano także członków Rady Przybocznej o brak odpowiedniej wiedzy o administrowaniu miastem ${ }^{14}$, a samą decyzję wojewody określono mianem samowoli ${ }^{15}$. Spotkała się ona z odpowiedzią rozwiązanej Rady Miejskiej, której członkowie zebrali się na tajnym posiedzeniu 24 lipca 1924 r. Otworzył je najstarszy radny, Adam Doboszyński, przekazując głos pierwszemu referentowi Stanisławowi Klimeckiemu, który skrytykował decyzję wojewody, nazywając ją „aktem bezprawia”, ponieważ jawnie naruszała $\S 53$ statutu $^{16}$. Przepis ten jasno określał procedurę postępowania w sytuacji rozwiązania reprezentacji gminnej, nakazując przeprowadzenie wyborów miejskich w ciągu sześciu tygodni oraz pozostawienie prezydenta i wiceprezydentów na swoich stanowiskach ${ }^{17}$. Radny Klimecki zwrócił uwagę nie tylko na aspekt prawny, ale także na argumenty użyte przez wojewodę oraz sam tryb wydania zarządzenia, wskazując, iż Prezydium Magistratu zostało poinformowane o nim w nocy, bez uprzedzenia, nie pozostawiając czasu na jakąkolwiek reakcję. Na zarzut wojewody o nielegalne funkcjonowanie Rady odpowiedział, że organ działał prawidłowo, a w warunkach braku nowej ordynacji wyborczej kooptacja radnych odbywała się zgodnie z prawem. Na zakończenie swojego przemówienia wniósł wniosek o podjęcie uchwały zmierzającej do zaskarżenia decyzji wojewody krakowskiego do Ministerstwa Spraw Wewnętrznych, a w razie konieczności także do Najwyższego Trybunału Administracyjnego ${ }^{18}$. W podobnym tonie wypowiedział się także poseł Emil Bobrowski, podkreślając nielegalność

10 Kozińska-Witt, „Stratni i wygrani?”, 115.

11 Dz. Urz. Woj. Kr. 5 (1924): 9; Adamczyk, „Samorząd Krakowa”, 55.

12 Dz. Urz. Woj. Kr. 5 (1924): 9.

13 „Rozwiązanie Rady Miejskiej”, Przegląd Kupiecki 30 i 31 (29 lipca 1924), 5.

14 „Po zamianowaniu Rady Przybocznej”, Głos Narodu 168 (26 lipca 1924), 1.

15 „Rozwiązanie Rady Miejskiej”, Kurier Wieczorny 164 (22 lipca 1924), 1, gdzie stwierdzono, że ,,[...] nagłem, samowolnem i najzupełniej niedostatecznie umotywowanem postanowieniem administracyjnem skasowaną została jeszcze jedna placówka czynnego życia samorządowego w państwie [...]”.

16 Protokół z „nadzwyczajnego tajnego posiedzenia Rady Miejskiej” z 24 lipca 1924 r., ANK, AmK, dok. $\mathrm{Kr} 4422-4424$ [b.p.].

17 Statut gminny, 27.

18 Protokół z ,nadzwyczajnego [...]”, ANK, AmK, dok. Kr 4422-4424 [b.p.]. 
decyzji wojewody. Żałował również, że na posiedzeniu zabrakło radnych wnioskujących o rozwiązanie Rady, licząc na wyjaśnienia z ich strony. Następnie głos zabrał wiceprezydent Sare, wyliczając dokonania krakowskich włodarzy i zrzucając odpowiedzialność za niepowodzenia na sytuację wojenną i zły stan kasy miejskiej. Dodał jednak, że dla dobra miasta będzie wspierał komisarza rządowego w jego pracy ${ }^{19}$. Kolejni referenci wtórowali przedmówcom, a radny Wacław Potuczek wniósł dodatkowo o podjęcie uchwały dotyczącej wyrażenia swojego ubolewania w stosunku do radnych, którzy wywołali kryzys. Zarówno ten wniosek, jak i złożony wcześniej przez radnego Klimeckiego uzyskały pełne poparcie zgromadzonych osób. Ponadto podjęto uchwałę powołującą dziewięcioosobowy komitet, którego zadaniem było opracowanie rekursu i dbałość o sprawy formalne, a także uchwały wzywającej komisarza oraz rząd do rozpisania wyborów miejskich ${ }^{20}$.

Powołany komitet wywiązał się ze swojego zadania, przygotowując 17-stronicowy rekurs do ministerstwa, w którym stwierdzono nieważność wydanej decyzji. Argumentowano, że Kraków jako miasto posiadające własny statut podlegał Tymczasowemu Wydziałowi Samorządowemu we Lwowie (TWS), przez co wojewoda krakowski przed wydaniem zarządzenia powinien był uzyskać jego zgodę albo przynajmniej porozumieć się w tej kwestii. Opinia ta miała znaleźć potwierdzenie w samej decyzji wojewody, który pouczył Radę Miejską o możliwości wniesienia odwołania do ministerstwa za pośrednictwem TWS. W statucie miejskim nie określono przesłanek stojących za rozwiązaniem Rady Miejskiej, dlatego przepisy w tej materii miały być interpretowane poprzez zastosowanie analogii do ustawy gminnej z $1862 \mathrm{r}$. Co za tym idzie, decyzja wojewody mogła być podjęta wyłącznie po przekroczeniu przez organ miejski swoich uprawnień, działaniu wbrew ustawom oraz gdy rada nie podjęła środków zaradczych w sytuacji gdy prezydent narażał dobro publiczne, wykonując zadania zlecone. Koronnym argumentem piszących skargę był fakt, że statut miejski nie przywidywał instytucji komisarza rządowego oraz rady przybocznej. Komitet przygotowujący treść rekursu wykazał przy tym brak podstawy prawnej, jaka powinna zostać przytoczona w zarządzeniu wojewody, jednocześnie podważając użyty w nim argument, jakoby Rada nie odpowiadała stosunkom społecznym i ekonomicznym miasta. „Gdzie klucz, gdzie kryterium tych stosunków społecznych czy ekonomicznych miasta?” - pytali retorycznie radni miejscy, stwierdzając, że użyte przez wojewodę sformułowanie było jedynie „ogólnikowym, pustym, nienadającym się do dyskusji frazesem”"21. Podkreślano, iż miasto było w dobrej kondycji finansowej, a szereg zrealizowanych inwestycji dowodził skuteczności Rady Miejskiej. Zaskarżając decyzję wojewody krakowskiego, radni argumentowali również, że skład Rady, choć pochodził z różnych źródeł, nie uległ zmianie od pięciu lat, a ponadto w podobnej sytuacji była większość małopolskich miast, których organy wybrano przed niedawno zakończoną wojną. Przypomniano także, że 30 maja 1919 r. uchwalono ordynację wyborczą, której ministerstwo nie rozpatrzyło ${ }^{22}$.

Rekurs trafił do Warszawy, o czym świadczy pismo skierowane do wojewody krakowskiego z wezwaniem do przesłania szeregu dokumentów potwierdzających skład Rady Miejskiej, źródła pochodzenia mandatów radzieckich, a także sprawozdania do-

19 Ibid.

20 Ibid.

21 Rekurs, ANK, AmK, dok. Kr 4422-4424 [b.p.].

22 Ibid. 
tyczącego Rady Przybocznej²3. W piśmie z 13 września 1924 r. wojewoda obarczył zadaniem przygotowania dokumentacji komisarza rządowego Wawrauscha ${ }^{24}$. Opracowane w ten sposób materiały przesłano do Ministerstwa Spraw Wewnętrznych, gdzie je przeanalizowano, wydając następnie decyzję z 24 lutego 1925 r. o odrzuceniu rekursu w części dotyczącej rozwiązania Rady Miejskiej, a część dotyczącą powołania komisarza rządowego pozostawiono bez rozpatrzenia ${ }^{25}$. Ministerstwo wskazało, że skarżący błędnie zinterpretowali przepisy ustawy gminnej i statutu miejskiego dotyczące pozostawienia na urzędzie radnych, wyjaśniając przy tym, iż ,ze statutu gminnego wynika niewątpliwie", że radni mogli pozostać na swoich stanowiskach po upływie kadencji, ale tylko w sytuacji, gdyby zarządzone z jej końcem wybory się nie odbyły albo nie zostały uprawomocnione. W tym przypadku nie miał zastosowania ten przepis, ponieważ w ogóle nie doszło do rozpisania nowych wyborów. Co więcej, ministerstwo argumentowało, że część radnych włączonych w skład Rady Miejskiej po przyłączeniu Podgórza do Krakowa pochodziła z mianowania, czego nie zakładał statut gminny. Podobny problem dotyczył radnych, którzy weszli do Rady na mocy rozporządzenia Tymczasowej Komisji Likwidacyjnej. W dalszej części ministerstwo dokonało interpretacji przepisów mających uprawniać do rozwiązania Rady Miejskiej i powołania komisarza rządowego, zbijając tym samym argumentację strony skarżącej ${ }^{26}$. Wyjaśnienia te znalazły się również w obszernym piśmie ministerialnym do NTA z 26 września 1925 r., w którym minister prosił o oddalenie skargi jako nieuzasadnionej ${ }^{27}$.

Tymczasem zmiany personalne dotknęły urząd komisarza rządowego. Wawrausch po roku zrezygnował z funkcji, co zatwierdził wojewoda krakowski w piśmie z 18 lipca $1925 \mathrm{r}^{28}$ Komisarza atakowała prawica polityczna oskarżająca go o brak dostatecznego zaangażowania i pomysłów na rozwój miasta ${ }^{29}$. Na łamach Głosu Narodu pisano, że komisarz „swoją biurokratyczną inercją i drobiazgowością oraz nieznajomością lokalnych warunków raczej utrudnia i hamuje wszelkie przedsięwzięcia i inicjatywę wybitniejszych urzędników miejskich" ${ }^{30}$. Szybko popadł też w konflikt z wiceprezydentami, a nawet Radą Przyboczną, która już w październiku 1924 r. zwróciła się do wojewody z wnioskiem o usunięcie Wawrauscha z urzędu ${ }^{31}$. Sympatycy komisarza przedstawiali go natomiast w zdecydowanie lepszym świetle, podkreślając jego „niezwykły takt osobisty", doświadczenie zawodowe i pozytywny wpływ na stan kasy miejskiej.

23 Pismo Ministerstwa Spraw Wewnętrznych do wojewody krakowskiego z 29 sierpnia 1924 r., ANK, AmK, dok. Kr 4422-4424 [b.p.].

24 Pismo wojewody krakowskiego do komisarza rządowego z 13 września 1924 r., ANK, AmK, dok. Kr $4422-4424$ [b.p.].

25 Pismo wojewody krakowskiego do komisarza rządowego z 28 lutego 1925 r., ANK, AmK, sygn. Kr $4422-4424$ [b.p.].

26 Ibid.

27 Pismo ministra spraw wewnętrznych do NTA z 26 września 1925 r., ANK, AmK, dok. Kr 4422-4424 [b.p.].

${ }_{28}$ Pismo wojewody krakowskiego do Z. Wawrauscha z 18 lipca 1925 r., ANK, AmK, sygn. Kr 44224424 [b.p.].

29 Adamczyk, ,Samorząd Krakowa”, 56.

30 „O sanację stosunków w Zarządzie m. Krakowa”, Głos Narodu 232 (11 października 1924), 3.

31 Wałdoch, Zarząd, 244; „O sanację stosunków w Zarządzie m. Krakowa”, Głos Narodu 232 (11 października 1924), 3; „Z kraju, W sprawie odwołania komisarza rządu”, Glos Lubelski 282 (14 października 1924), 3. 
Odpowiedzialnością za wszelkie niepowodzenia obarczano zaś oponentów politycznych, którzy dążyli do zdyskredytowania Wawrauscha ${ }^{32}$. Na urzędzie zastąpił go znany w środowisku samorządowym Witold Ostrowski, dotychczasowy radny miejski i naczelnik Wydziału Przemysłowego w urzędzie wojewódzkim, który cieszył się poparciem lewicy, a także wiceprezydentów, w opozycji zaś znaleźli się reprezentanci chadecji i endecji. W sprawę zaangażowali się nawet posłowie chadeccy oraz należący do Związku Ludowo-Narodowego, którzy wnieśli do ministra Władysława Raczkiewicza o uchylenie decyzji wojewody krakowskiego, oskarżając go o nielojalność wobec Rządu ${ }^{33}$. Z artykułu zamieszczonego w Głosie Narodu wynika, że chodziło nie tyle o osobę Ostrowskiego, ile o postępowanie wojewody, który powołał komisarza bez konsultacji ze stronnictwami. Ich zabiegi okazały się jednak bezskuteczne, a Ostrowski wytrwał na swoim stanowisku przez rok, do 2 czerwca 1926 r., kiedy zgodnie z decyzją wojewody krakowskiego kierowanie magistratem powierzono wiceprezydentowi Saremu, polecając mu przygotowanie wyborów miejskich ${ }^{34}$.

Decyzja wojewody wynikała z orzeczenia NTA wydanego w sprawie skargi radnych na rozwiązanie Rady Miejskiej w 1924 r. W dniu 11 lutego 1926 r. NTA poinformował strony o terminie rozprawy głównej, którą zaplanowano na 15 marca 1926 r. o godz. 10:00 z wezwaniem pełnomocników do osobistego stawiennictwa ${ }^{35}$. Stronę skarżącą reprezentowali: Fryderyk Zoll (profesor UJ i krakowski radny), Adolf Gross oraz Stanisław Klimecki, a pełnomocnikiem strony pozwanej był radca ministerialny Tadeusz Saloni ${ }^{36}$. W wyroku z 26 kwietnia 1926 r. NTA orzekł, że „uchyla zaskarżone orzeczenie zarówno z powodu wadliwego postępowania i niezgodności z ustawą "37. Stwierdzono, że przy podejmowaniu decyzji o rozwiązaniu Rady Miejskiej wojewoda pominął czynnik samorządowy w postaci TWS, a treść zarządzenia stała w sprzeczności ze statutem, a także z ustawą gminną, w której wskazano przesłanki rozwiązania reprezentacji gminnej niewystępujące w przypadku krakowskiej Rady Miejskiej ${ }^{38}$.

Wyrok NTA wzbudził emocje nie tylko w samym Krakowie, ale też w polskim środowisku administratywistów i prawników, będąc przedmiotem szerszych komentarzy Jerzego Panejki oraz Jerzego Stefana Langroda, którzy krytycznie odnieśli się do treści orzeczenia. Pierwszy z badaczy przedstawił na wstępie swojego artykułu zamieszczonego w Samorządzie Terytorialnym ${ }^{39}$ podstawy prawne, na których opierał się samorząd krakowski, i dokonał interpretacji przepisów odnoszących się do kwestii nadzoru oraz rozwiązania reprezentacji gminnej. Tym sposobem Panejko doszedł do wniosku, iż przepisy ustawy państwowej z 1862 r., powielone następnie w $§ 112$ statutu, dawały

32 Wałdoch, Zarzą, 245; „Radca wojew.[ódzki] Witold Ostrowski komisarzem rządowym m. Krakowa”, Ilustrowany Kurier Codzienny 197 (20 lipca 1925), 9.

33 Wałdoch, Zarzad, 245; „Ch. D. i Z. L. N. przeciw nominacji p. Ostrowskiego”, Głos Narodu 166 (22 lipca 1925), 1.

34 Decyzja wojewody krakowskiego z dnia 2 czerwca 1926 r. w sprawie „reaktywowania rozwiązanej Rady Miejskiej w Krakowie” (L.A.S.5442/26), ANK, AmK, dok. Kr 4422-4424 [b.p.].

${ }_{35}$ Pismo NTA ,do rozwiązanej Rady miejskiej stoł. m. Krakowa” z 11 lutego 1926 r., ANK, AmK, dok. $\operatorname{Kr} 4422-4424$ [b.p.].

36 Orzeczenie wyroku NTA (L.Rej.1325/25), ANK, AmK, dok. Kr 4422-4424 [b.p.].

37 Ibid.

38 „Wyrok Trybunału administracyjnego w sprawie rozwiązania Rady Miejskiej w Krakowie”, Gtos Narodu 96 (28 kwietnia 1926), 1.

39 Zob. Panejko, „Rozwiązanie”. 
władzy nadzorczej prawo do rozwiązania reprezentacji gminnej i co znamienne, przepis ten był „samoistnym bezwarunkowym postanowieniem”, uprawniającym organ władzy II instancji „do wkroczenia w każdym czasie [wyróżn. oryg.] w działalność reprezentacji gminnej, jeśli ta, zdaniem tej władzy, nie odpowiada swemu przeznaczeniu"40. Uprawnienie to istniało obok katalogu podstawowych środków nadzorczych. Trybunał natomiast uzasadniał wyrok tym, że:

Prawo nadzoru [...] nie może być tłumaczone w ten sposób, by władze państwowe granice tego nadzoru, określone ściśle istniejącymi ustawami, mogły wedle swego swobodnego uznania rozszerzać. Sprzeciwiałoby to się bowiem duchowi istniejącego w tej mierze ustawodawstwa, w którym idea samodzielności samorządu uwidacznia się coraz silniej ${ }^{41}$.

Według NTA chodziło tu o realizację zasady, że ,podstawą wolnego państwa jest wolna gmina"42. Panejko skrytykował te twierdzenia, uznając, że nie należy powoływać się na ducha archaicznego ustawodawstwa, gdyż ono nie odpowiadało ówczesnym stosunkom społecznym i politycznym. To prawo i interpretacja przepisów powinny podążać za dokonującymi się zmianami, jakie nie ominęły także myśli samorządowej. Autor stwierdził, że dziewiętnastowieczna koncepcja pouvoir municipal wraz z jej założeniami o przyrodzonych, suwerennych i nienaruszalnych prawach gminy została w całości odrzucona jako relikt teorii „dążącej do usunięcia absolutno-feudalnych metod rządzenia”, stąd „wolność gminy”, rozumiana była wówczas jako przeciwstawienie się państwu. Panejko zupełnie inaczej patrzył na gminę stanowiącą dla niego jeden z organów państwowych powołanych do współdziałania z administracją rządową na zasadzie samodzielności, a nie samowoli ${ }^{43}$. Badacz dostrzegł jednak, że we Lwowie i w Krakowie powołanie komisarza rządowego było nielegalne, ponieważ statuty tych miast jasno określały rolę prezydenta i wiceprezydentów w sytuacji rozwiązania rady miejskiej. $\mathrm{Na}$ koniec artykułu zadał on pytanie, pozostawiając je bez odpowiedzi, co należy zrobić, gdy problem danej gminy nie leży w jej organach, lecz w niedojrzałej społeczności. W takiej sytuacji nowe wybory nie przyniosłyby pozytywnego skutku, a jedynie uwidoczniłyby bezsilność administracji rządowej ${ }^{44}$.

W podobnym tonie wypowiedział się Langrod, który w swojej monografii przedstawiającej problem rozwiązania Rady Miejskiej Krakowa w 1931 r. poruszył także podobną sprawę sprzed pięciu lat, podkreślając „rażącą błędność” wyroku NTA z 1926 r. Langrod - podobnie jak wcześniej Panejko - twierdził, że powoływanie się na skostniałe ustawodawstwo stało w sprzeczności z nowoczesnym wyobrażeniem samorządu terytorialnego, w którym nie było już miejsca na austriacką, a tym bardziej francuską, teorię o przyrodzonej wolności gminy ${ }^{45}$. Langrod krytycznie wypowiedział się na temat uzasadnienia wyroku i zawartej w nim interpretacji przepisów, utrzymując, że prawo do rozwiązywania reprezentacji gminnej „może być wykonywane bez ograniczeń”,

\footnotetext{
40 Ibid., 5-6.

41 Cyt. za: ibid., 8.

Ibid.

Ibid., 12-3.

Ibid., 19.

45 Langrod, 3 lata, 21.

46 Ibid., 22.
} 
a „samorząd ma być pojęciowo łącznością, harmonią i zespoleniem”, a także „formą organizacyjną" służącą miejscowej społeczności do nauki odpowiedzialności ${ }^{47}$.

W piśmie z 2 czerwca 1926 r. wojewoda krakowski poinformował wiceprezydentów Krakowa o odsunięciu komisarza rządowego i Rady Przybocznej od pełnionych funkcji oraz jednocześnie przekazał wiceprezydentowi Saremu urząd prezydenta miasta do czasu przeprowadzenia wyborów. Reaktywowana Rada Miejska zebrała się po raz pierwszy od dwóch lat 11 czerwca 1926 r., a 19 czerwca wybrała nowego prezydenta w osobie Rollego, który zdobył poparcie 80 ze 107 głosujących radnych. Jego zastępcami zostali: Józef Sare, Piotr Wielgus, Witold Ostrowski oraz Ludwik Schneider. Uroczyste zaprzysiężenie prezydenta odbyło się 4 września 1926 r. w gmachu Towarzystwa Wzajemnych Ubezpieczeń przy ul. Basztowej 8.

Sprawa rozwiązania Rady Miejskiej z 1924 r. pogłębiła dyskusję nad rolą samorządu terytorialnego w nowoczesnym państwie. Uwidoczniła się wciąż żywa koncepcja silnej, niemal niezależnej gminy, reprezentowana wówczas przez NTA, oraz teoria państwowa samorządu, w której ten był jedynie elementem aparatu administracyjnego państwa opartym na zasadzie współdziałania z administracją rządową. Debata rozgorzała ponownie w 1931 r., kiedy wojewoda krakowski po raz kolejny rozwiązał Radę Miejską, powołując organ tymczasowy o kompetencjach Rady pochodzącej z wyborów, złożony jednak wyłącznie z osób mianowanych.

\section{Bibliografia}

\section{Źródło archiwalne}

Archiwum Narodowe w Krakowie, Akta miasta Krakowa sygn. Kr 4422-4424 [ANK, AmK, dok. $\mathrm{Kr}$ 4422-4424].

\section{Źródła drukowane}

Głos Lubelski (1924).

Gtos Narodu (1924, 1925, 1926).

Ilustrowany Kurier Codzienny (1925).

Kurier Wieczorny (1924).

Przegląd Kupiecki (1924).

\section{Źródła prawne}

Statut gminny dla stoł[ecznego] król[ewskiego] miasta Krakowa. Kraków, 1916.

Zarządzenie wojewody krakowskiego Władysława Kowalikowskiego z dnia 19 lipca 1924 r.

(L 9482/pr) o rozwiązaniu Rady Miejskiej Krakowa i wprowadzeniu zarządu komisarycznego (Dz. Urz. Woj. Kr. 1924 nr 5).

47 Ibid., 21.

Artykuły - Articles 


\section{Opracowania}

Adamczyk, Elżbieta. „Samorząd Krakowa i jego władze”. W: Dzieje Krakowa. T. 4: Kraków w latach 1918-1939, red. Janina Bieniarzówna, Jan M. Małecki, 51-78. Kraków: Wydawnictwo Literackie, 1997.

Kozińska-Witt, Hanna. „Stratni i wygrani? Postrzeganie państwa przez działaczy samorządowych byłej Galicji przed i po wydaniu ustawy scaleniowej (1933)". W: Państwo i społeczeństwo Drugiej Rzeczypospolitej, red. Janusz Żarnowski, 109-23, Warszawa: Instytut Historii PAN, 2014 (seria „Metamorfozy Społeczne”. Tom 8).

Kozińska-Witt, Hanna. „Udział Żydów w wyborach do Rady m. Krakowa i w jej składzie w okresie Drugiej Rzeczypospolitej - prasowa wersja wydarzeń". Kwartalnik Historii Żydów 4 (2013): 647-78.

Langrod, Jerzy Stefan. 3 lata samorządu Krakowa (1931-1933) na tle teorji prawa administracyjnego. Fakty i konkluzje. Kraków: Księgarnia S.A. Krzyżanowski, 1934.

Małecki Jan M. „W dobie autonomii galicyjskiej”. W: Dzieje Krakowa. T. 3: Kraków w latach 1796-1918, red. Janina Bieniarzówna, Jan M. Małecki, Józef Mitkowski, 225-394. Kraków: Wydawnictwo Literackie, 1979.

Panejko, Jerzy. „Rozwiązanie reprezentacji komunalnych w województwach b. zaboru austriackiego". Samorzą Terytorialny 4 (1929): 1-19.

Wałdoch, Jacek. Zarzad komisaryczny w wielkich miastach II Rzeczypospolitej. Studium historyczno-prawne. Gdańsk: Wydawnictwo Uniwersytetu Gdańskiego, 2020. 
